\title{
Historical Perspectives on Marriage, Migration, and Family Networks in the Region of Kayes, Mali
}

Perspectives historiques sur le mariage, les migrations et les réseaux familiaux dans la région de Kayes, Mali

Perspectivas históricas sobre casamiento, migración y redes familiares en la región de Kayes, Mali

\section{Marie Rodet}

\section{(Q) OpenEdition}

\section{Journals}

Electronic version

URL: https://journals.openedition.org/remi/7166

DOI: $10.4000 /$ remi.7166

ISSN: $1777-5418$

\section{Publisher}

Université de Poitiers

\section{Printed version}

Date of publication: 1 January 2015

Number of pages: $39-55$

ISBN: 979-10-90426-24-5

ISSN: 0765-0752

\section{Electronic reference}

Marie Rodet, "Historical Perspectives on Marriage, Migration, and Family Networks in the Region of Kayes, Mali", Revue européenne des migrations internationales [Online], vol. 31 - $n^{\circ} 1$ | 2015, Online since 01 January 2018, connection on 14 April 2022. URL: http://journals.openedition.org/remi/7166 ; DOI: https://doi.org/10.4000/remi.7166 


\section{Historical Perspectives on Marriage, Migration, and Family Networks in the Region of Kayes, Mali}

\section{Marie Rodet ${ }^{1}$}

Since the 1990s and in spite of the rediscovery of the migration experiences of African women, very little historical research has been conducted on the mobility patterns of West African women. ${ }^{2}$ While contemporary West African women's migration continues to attract much scholarly attention, African female migrations prior to the 1970s still remain largely understudied (CoqueryVidrovitch, 1994: 125). One of the main mobility patterns neglected by African historians is certainly that of marriage migration. ${ }^{3}$ As marriage in West Africa has been mainly exogamic (outside of the immediate social unit) and virilocal (the married couple residing with the husband's family), the movement of women in and out of marriage always involved some kind of migration. Although the number of female migrations linked to marriage probably consistently exceeded that of the male labour migration in West Africa, marriage migrations have long been considered as less significant. Moreover, women have long been regarded as simply embedded in tradition and therefore as living outside the dynamics of historical development (Rodet, 2008: 167). African men on the other hand were encouraged through colonization to become "modern", "educated" and "wageorientated" (Rodet, 2007a: 30). Even when women were joining their migrating husbands because of marriage, they were not considered other than "passive migrants" who accompanied their husbands who had wage-labour jobs in urban centres. Studies were focused on male labour migration, which ultimately obscured any other kind of mobility taking place outside this framework.

In this article and following Watts's steps (Watts, 1983: 682-698), I argue that migration scholars can gain a wider understanding of African migration through

1 Lecturer in the History of Africa, History Department, School of Oriental and African Studies, University of London; mr28@soas.ac.uk

2 Some notable exceptions, however, are certainly Cordell, Gregory and Piché (1996); Lambert (2002); Goerg (2004 and 2005); Dougnon (2007). Historical migrations of African women have been much more researched with regard to South and East Africa. See among others: Bozzoli (1991); Wright (1995), Walker (1990); Barnes (1999 and 2002). While being significant contributions to the field of African historical migration, most of these studies remain focused on urban and/or labour migrations. For a critical analysis of such perspective, see Rodet (2009a: 15-27).

3 This migration pattern has been much more researched with regards to other continents, especially Asia; see Fan and Huang (1998) and Women in Action (2007). 
the examination of marriage migration in particular. Indeed, focusing on the study of migration in terms of marriage affords a better grasp of the important long-standing social and economic changes experienced by West African societies during the colonial era.

The literature rarely distinguishes between migration, mobilities and circulation. Here, I favour the use of migration over mobility, as it seems to me that the generally-accepted meaning of this term is broader than that of "mobility". The latter effectively excludes the possibility of periods of immobility or pause within the migratory path. I mostly use mobility when I associate it with the concept of social mobility. But we must be wary of an abusive use of this term as it leads to a scientific questioning of the success or failure of the migration, and whether it is emancipating or alienating - which are highly subjective and often essentialising factors. I use the term circulation, but in reference to a particular form of migration constituted of successive displacements and return trips, which often reinforce patterns of multilocality: because of a long history of migration between specific regions, cultural contexts and social relations end up being linked over and between several geographical spaces, defying borders, forming a specific cultural and social continuum between these regions.

In this article, I adopt a "comprehensive" definition of migration, allowing me to show the connections between the different forms of migration, which often have fluid boundaries. Migration is here taken to mean, in an African context, any change of residence (at a local, regional, or intra/intercontinental level), temporary or permanent, which takes place outside of the space of a given community (such as a village or town).

My study of marriage migration is specifically concerned with the region of Kayes, situated in the western part of the Colony of French Sudan (now known as Mali), at the border with Senegal. The Kayes region is well known for its long migration history (Adams, 1977; Weigel, 1982; Manchuelle, 1997). There is extensive literature on male labour migration out of this area. But as shown in previous research, scholarship on female migration in the region remains rare (Rodet, 2009a), even in recent times. ${ }^{4}$ In Willing Migrants, a study of Soninke migrations between 1848 and 1860, François Manchuelle's only comment on female migration from the region to Senegal is that women started migrating in the late 1950s to join their husbands in Dakar where they had already been labour migrants for many years (Manchuelle, 1997: 191). In this article, I argue that marriage migration has a much longer history and should not be reduced to a simple "catching up" phenomenon as seems to be implied by Manchuelle's elusive description of women's migration to Dakar.

The research for this article is mainly based on transcripts of court cases found in the Malian archives for the first quarter of the twentieth century, and on interviews conducted in 2003-2004 within the framework of my PhD thesis. Roberts (2005) and Burrill (2007) have extensively worked on similar court transcripts proving the importance of such sources to reconstruct the social history of marriage in colonial Mali. But they never used such sources to study women's

4 I have been able to locate only two studies on contemporary female migrations from the Kayes region: Findley and Diallo (1995); Konaté (2010). 
historical migration, mobility and circulation. Yet, court cases are precious sources of information about migrations and gender conflicts taking place against the backdrop of increasing colonial control. Indeed, the majority of the cases heard by the colonial courts of Kayes, Bafoulabé and Nioro from 1907 to 1925 were marriage disputes involving female migration (through desertion and divorce). From 1907 to 1912, the marriage cases heard by the court of Kayes, the busiest court of the region at the time, represented more than a third of all civil litigations, of which $65 \%$ were divorce cases and $30 \%$ involved desertion of the marital home. As we shall see, the attempts made by women of the region to increase their social and geographical mobility were often at the origin of these marital disputes. In the patriarchal societies of Kayes, adult women's mobility was often subordinated to their husband and/or in-laws' approval and the support of their own relatives.

But the very incomplete state of these legal archives for the time period of 1907-1925 is one factor which makes the use of these sources complex and may even question their representativeness. ${ }^{5}$ For 1905-1912, the series are relatively complete. But I was unable to locate complete series for the later period. My corpus is of 1,100 civil cases for the time period of $1907-1912^{6}$ and fifty-two cases for 1920-1925. Court transcripts are usually very brief and elusive on the precise context of the litigation. Very often, it is impossible to find such details as the age, social status, and ethnicity of the litigants, which would be crucial to approach female mobility in intersectional terms. ${ }^{7}$ Unfortunately, this lack of detail can mistakenly encourage the reader to generalize about female mobility from a few random cases. We do not know either the extent to which local populations resorted to these courts in order to sort out their martial disputes, even if colonial authorities regularly insisted on the increasingly overwhelming caseload they had to deal with every year (Rodet, 2011). These cases only shed light on a segment of behaviours, but their repetitiveness over twenty years and a cross-examination with other colonial documentation, as well as collected life and family histories, can give us nonetheless some insight into possible migration strategies used by the local populations, and women in particular, during the colonial period.

Indeed, life and family histories and further archival documentation help to recontextualize migrations linked to marital disputes within broader patterns of high population mobility such as that experienced by the Kayes region at the time. Yet, legal records show that the main specificity of female mobility is that of its increasing restriction over the first quarter of the twentieth century by

5 During my research in 2008-2010, I have discovered unclassified legal records in cercle (district) archives of the Kayes region. These may yield more information for future research.

6 From 1907 to 1912, the court of Kayes heard 748 civil cases, the court of Bafoulabé 264 civil cases and the court of Nioro 88 civil cases.

7 The concept of intersectionality originates in African-American feminist theories, which, from the 1970s onward, have attempted to call into question the "white supremacy" of second-wave feminists. This concept allows us to rethink our relationships with others and with ourselves, not only through the prism of gender but by recognizing the way gender identities are shaped by other facets of identity, such as class, culture, sexual orientation, age, generation, and so on. This complexification of gender analysis throws light upon the multiple aspects of oppression and undermines essentialist conceptions of femininities and masculinities. 
the colonial authorities with the help of the local power and the courts. In this context, women attempted to navigate these shifting colonial and local landscapes of power by developing specific "circumventing" strategies.

Marital disputes are often described by academics as "situation of rupture" and seen as prevalent forms of women's resistance to the "patriarchal order". However, if we approach these situations merely as a form of "migration of rupture", our analysis remains within the dualistic conceptual framework of "resistant and active agents" vs. "victims and passive agents". The use of concepts such as "resistance" alone tends to overlook the plurality of women's experiences and to underestimate the diverse bricolages some of them combined to adapt to the shifting colonial and social environment and renegotiate their relation with the local power. Sources available do not allow us to assess with precision the extent to which these women had a desire per se to migrate. Nonetheless, their mobility as such proves that they were migrating for diverse reasons, even if for some of them, the exact motivation behind their migration may not have been clearly expressed.

As shown in the first section of this article, marriage disputes shed light on some "circumventing" strategies used by some women to increase their social and geographical mobility. In the second section, I then examine the constitution of specific family networks over several generations through marriage to reinforce multilocality and circulation between Mali and communities abroad. Some women, through their marriage migration and their subsequent regular circulation between regions of origin and regions of migration, played a central role in maintaining these networks, despite an increasing colonial and local control of their mobility.

\section{Negotiating Marriage and Family Networks}

Scholarship over the last twenty years on migration has focused particularly on the importance of family and social networks in the migratory process (Boyd, 1989: 639). In the case of family networks, families left behind in the region of origin would be connected to several specific destinations of potential migration (Root and De Jong, 1991: 223). These networks link migrants and non-migrants in a complex web of interpersonal relationships producing a significant information exchange, and sustained social, financial and moral support between region of migration and region of origin (Boyd, 1989: 639). These family networks would be especially crucial to pass on reliable information about migration opportunities as obligations between members of the same family were seen as more stable than those of unrelated people (Pflegerl, 2003: 79-83).

However, this network analysis has been mainly applied to research on today's international migratory movement. In contrast, the research on regional African women's migration taking place before the 1960s has not attracted such analysis. We have very little information and few written sources relevant to migration within the rural areas. But the legal records from the colonial courts in

8 On the analysis of "runaway women" and female desertion as a form of women's resistance, see in particular Mbilinyi (1989) and Schmidt (1992: 92-93). 
Western Mali, especially marriage cases such as divorce, desertion of the marital home and bridewealth reimbursement, provide information in abundance on women's migration.

Traces of regional female migration are found particularly in legal cases where the husband comes to court complaining about his wife not returning from visits to parents. Where family visits lasted for several months, during which visiting women were seen to have taken part in the social and economic life of the family, we can see such visits as more than just simple family obligation. I argue in this article that in such cases they can be regarded as proper patterns of migration.

The migratory behaviour of women in the region of Kayes was often influenced by family considerations. A woman was all the more willing to migrate if she was sure that she could rely upon the support of a relative. Women seized the opportunities offered by their own family networks to enable their mobility. Family networks were especially vital for women since their circulation suffered more control than that of men, in that their mobility was often constrained by their husband's and/or in-laws' approval when they were married (Rodet, 2009b: 28-29). The husband would be more likely to allow his wife to leave knowing where she was going and with which family member she would be staying. Indeed, according to custom the husband could not disallow his wife to leave for a visit to her family. Female migration was often following the precedent set by previous migrating family members.

Several court cases have clearly illustrated the plurality of the predicaments in which women from the region of Kayes found themselves in when resorting to family networks in order to migrate. In November 1910, Mori went to the court of Nioro to complain about his wife who had left him and who lived at this time with Mallé. ${ }^{9}$ Malle explained to the judge that the woman was his relative which is why he agreed to her living at his place. The court finally approved the divorce and ordered Mallé to reimburse Mori with the bridewealth. In April 1911, Yoro from Bambella asked the court of Kayes to authorize his divorce with his wife Najo who had left him in order to follow her brother, a tirailleur, ${ }^{10}$ in Kayes. She refused to return to her husband because of his mistreatment of her. The court pronounced the divorce but forced Najo to return the bridewealth of 100 francs.

The judicial records show the bricolages to which women resorted in order to increase their mobility on a temporary or permanent basis. In the first years of their existence, the courts of the region of Kayes were inclined to grant divorce to deserting women who asked for it and whose husbands agreed to

\footnotetext{
9 ANM Koulouba (FA) 2 M 135: État des jugements rendus en matière civile et commerciale par le tribunal de province de Nioro. $4^{\text {th }}$ trimester 1910 . Due to privacy concerns raised by the regulation issued by the Republic of Mali in 2002 restricting the use of any records held by the National Archives of Mali that may "implicate the private lives of citizens", I use only the first name to identify disputants in court cases. For more information on court cases and privacy, see Roberts (2005: xi-xii).

10 The tirailleurs were the colonial soldiers recruited by the French Army in the French African colonies from the nineteenth century.
} 
it. ${ }^{11}$ From 1910, the mobility of women in the Kayes region became more and more controlled. The jurisprudence of the Kayes court in the first twenty years of the twentieth century demonstrates that women deserting their husbands, or willing to divorce, were increasingly forced to return to their husbands, especially from the 1920s: desertion became a crime whose female perpetrators had to be punished when they refused to return to the marital home, since deserting women were thought to be a threat to social and economical stability. Henceforth deserting women refusing to return to the marital home would be systematically sentenced to imprisonment (Rodet, 2009). This criminalization of female mobility in and out of marriage was also encouraged by the colonial administration which feared the "disintegration of the native communities" (Rodet, 2010: 82-84). The decree of $24^{\text {th }}$ April 1928 stated that women could not migrate without the authorization of their husband, father or guardian. ${ }^{12}$ They would otherwise risk being accused of deserting the marital home. However, the colonial administration was never successful in enforcing the decree of $24^{\text {th }}$ April 1928. The control of the jurisprudence of the local courts was seen to be far more effective than colonial laws in the control of women.

Because of the increase in control over the mobility of women, those who could be supported by their family used the chance afforded by an official visit to the family, which could not be refused by the husband. In some cases but not all, this could be premeditated or purposely to pressurize renegotiation of marriage terms. In June 1907, Fatimata asked the Nioro court for a divorce from her husband Amadou because he did not support her adequately with food or clothing from the beginning of their 18-month marriage. ${ }^{13}$ Her husband explained to the court that he had allowed his wife to visit her aunt but, after three months of her being absent, he went to collect her as she had refused to return. Having examined more evidence offered by the husband, the court decided in this case against Fatimata.

In some cases, women were successful in taking advantage of the family visit to first, separate from their husband, and eventually to remarry. In June 1908, Massadio, who was married to Dionké, declared to the court of Bafoulabé that his wife had visited her brother and married another man. ${ }^{14}$ The divorce was granted. Another case shows how family members tried to use to their advantage the woman's migratory circumstances in order to settle a disagreement with the husband. Here we clearly see the family's complicity in prolonging the woman's stay. In July 1910, Moussa came to the Nioro court to ask his sister's husband, Mahamadou, to pay the remainder of the bridewealth. ${ }^{15} \mathrm{His}$ sister asked him to stay with him following the abuse she had suffered from her

11 Divorce would ordinarily be granted only if the husband agreed to it. If he did not, the woman was simply sent back to her husband for a lack of valid grounds for divorce.

12 ANS GGAOF (FA) 21 G 37(17): Arrêté du 13 mai 1928 portant réglementation de I'émigration et de la circulation des indigènes en Afrique occidentale française.

13 ANM 2 M 135: état des jugements rendus en matière civile et commerciale par le tribunal de province de Nioro. $2^{\text {nd }}$ trimester 1907.

14 ANM Koulouba (FA) 2 M 103: état des jugements rendus en matière civile et commerciale par le tribunal de province de Bafoulabé. $2^{\text {nd }}$ trimester 1908.

15 ANM 2 M 135: état des jugements rendus en matière civile et commerciale par le tribunal de province de Nioro. $3^{\text {rd }}$ trimester 1910. 
husband who, she claimed, repudiated her. The husband denying the charge declared to the court that she had simply asked him for divorce in exchange for the return of the bridewealth. The court stated that there was no reason for granting divorce and so ordered the wife to return to the marital home.

The attitude of the family often appeared ambiguous depending on the interests at stakes regarding the migration. The family members could, for example, support the wife at first, but then also change their minds when realizing that they would risk losing the bridewealth in the case of a divorce. In September 1920, Sadio came to the court of Bafoulabé to complain about his wife Penda who had abandoned him to join her brothers who, he alleged, had persuaded her to demand a divorce. ${ }^{16}$ He said that he had been married with Penda for more than twenty-five years and had four children with her. He suspected that she wanted a divorce because he was becoming old and blind. Penda replied to the court that she decided to get a divorce because of an argument with her husband in which he told her he had bought her as a slave. In fact, Penda had been the slave of Sambou, the head of the village. Sambou received the bridewealth when Penda married Sadio. Penda's brother confirmed her statements. He no longer wanted this marriage. However, Penda was instructed by the court to return to the marital home. She appealed against this judgment. It is with the process of appeal that we can clearly see the real family issues in this case. During the appeal process, Penda's brother said that his sister had first come to him for help to obtain a divorce after her husband had called her a slave. ${ }^{17} \mathrm{He}$ tried to discourage his sister and to convince her to return to her husband, but finally he accepted the situation and accompanied her to court to ask for a divorce. As her brother, he asked the court for the bridewealth of four cows originally given to Penda's former master, Sambou. Penda was subsequently ordered to return to her husband because of lack of grounds for divorce, the court acknowledging the right of the brother to the bridewealth.

The receipt of the brideprice could motivate a relative, such as a brother, to help a woman obtain a divorce and remarry. The relative who had taken care of her second marriage would receive the bridewealth. In 1922, Ousmane, based in Dakar, sent a letter to the Dakar administration asking them to contact the Kayes administration with regard to a petition he had addressed to the president of the Kayes court to which he had not received a reply. In this petition, he asked the president to call before him his sister's husband. ${ }^{18}$ The sister Hava had come to stay with him following the abuse she had allegedly suffered from her husband. She complained of lack of food and clothing, and that she was frequently beaten. Receiving no reply to his first letter and believing his sister's allegations, while at the same time considering that her husband had never made any effort to find out where she was or to seek any form of reconciliation, the brother went to the Kadi, the president of the Dakar Muslim court. The latter subsequently certified by letter that Hava was officially divorced. Ousmane said that he was ready to again offer his sister in marriage in the case of a suitable candidate

16 ANM 2 M 103: état des jugements rendus en matière civile et commerciale par le tribunal de subdivision de Bafoulabé. September 1920.

17 Id., tribunal de cercle de Bafoulabé. October 1920.

18 ANM Koulouba (FR) 2 M 211: réclamation. Ousmane Bokoum à délégué du gouvernement du Sénégal à Dakar. 20 February 1922. 
being interested. The Kayes administration eventually replied to Dakar that the president of the court had sent Ousman's first letter to the husband Djibi but that he had never answered. It was only recently that the husband came to Kayes and declared:

"My wife left me for no reason; the divorce was never pronounced and I never got the bridewealth reimbursed. (...) Already once before, my wife abandoned me to go to Matam where she got married again without having divorced, she only rejoined the marital home after the intervention of the Commandant of the cercle..$^{19}$ "

We can imagine here that Hava preferred to go to Dakar because she hoped that distance this time, unlike what happened when she migrated to Matam, would "protect" her more. It is also possible that after the failure of the first attempt she preferred to secure the support of her brother in Dakar who knew the workings of the colonial state and the religious power sufficiently enough to be able to help her with the defense of her case. His brother knew exactly how to address a petition to the legal administration in Kayes, to the Kadi of the Muslim court and to the colonial administration in Dakar. Unfortunately, the archive record does not give us the outcome of this case.

However, it would be misleading to deduce from these cases that migration occurring within the framework of the "visit to the family" only affected deserting women willing to get a divorce. These cases are the ones visible in the archives but the phenomenon of the family visit is part of a larger process of "multilocality" where the members of the same family were able to migrate and circulate, on a temporary or even a long-term basis, which was dependent upon which the opportunities existed in terms of the location of the family residence. ${ }^{20}$ This phenomenon has always been reinforced by the frequency of intermarriage between the region of origin and that of migration.

\section{Marriage Migration and Circulation Strategies}

In 1942, the administrator of the Kenieba District, noticed that the gender ratio in the region was 88.2 women to 100 men. ${ }^{21} \mathrm{He}$ explained this imbalance by the fact that most of the Fulbe families sent their daughters to marry in Guinea where they could find a much better match than in French Sudan. In order to change this imbalance, the administrator decided to impose a ban on young women leaving the region. The fluctuations of the population in the region show an intense circulation of people between French Sudan and Guinea. It was reinforced by interregional marriages which allowed families to consolidate family networks and to find new residential possibilities. This phenomenon is generally little documented in the archives as civil records are missing. It is therefore difficult to trace from which region married women were originally from and if there were many women from the same region marrying in another region.

19 Id., lettre du 27 mars 1922. Délégué du gouverneur à Kayes au gouverneur du Soudan français à Koulouba.

20 For a comparative perspective on the centrality of multilocality in migratory strategies in the Senegalese context, see Lambert (2002).

21 ANM Koulouba (FR) 1 E 25: rapport sur le Malotembaya. 1942. Cercle de Bafoulabé. Subdivision de Kéniéba. 
However, several of my interviews, in Senegal, in 2003, show that intermarriage between region of origin and region of migration has always been common. Ibrahima Dabo was born in 1925 in Lafanding in the cercle of Bafoulabé. ${ }^{22} \mathrm{He}$ went to Senegal at the beginning of the 1950s to work on peanut fields. He worked for one season in Kidira where his cousin from Kayes lived with her husband. The husband convinced him to stay to work for the railway. $\mathrm{He}$, himself, had been recruited for the forced labor on the Kidira railway a few years before and had settled there after his marriage to Ibrahima's cousin. In time, Ibrahima settled in Kidira where he married the daughter from a Bambara from the region of Beledougou who had gone to Senegal to farm peanuts.

In this account, we see that it was the marriage of the cousin with a migrant to Kidira which had allowed the subsequent arrival of other family members and in doing so initiated a family network to Kidira. Ibrahima's story also shows how migrants married off their children with other migrants in order to maintain effective links with the region of origin. Ibrahima's father in law only wished to marry off his three daughters to somebody from Mali.

Another interview allows us to better understand the series of intermarriages occurring over several generations between Mali and Senegal. Rama Diakhaté was born in Pire, Senegal, in 1933. ${ }^{23}$ Her father was originally from Kita (Region of Kayes, Mali). He left, in 1914, for Niassane, Senegal. He married Rama's mother in Senegal. The father of Rama's mother was originally from the Kayes region which he left at the point of the First World War having been recruited in the French Colonial Army. He went first to Senegal for military training and was sent to Morocco where his first wife, from the region of Kayes in Mali, joined him. There they had a daughter who was Rama's mother. Then Rama's maternal grand-father settled permanently with his family in Louga, Senegal. Rama's husband was from the region of Kayes (Yaguiné). He went first to Kaolack to cultivate peanuts and afterward was recruited by the railway. Rama met him in Louga while he was working for the railway. They married and moved to Rufisque. At the time of the break up of the Mali Federation in 1960, Rama and her husband returned to Bamako in Mali where they stayed for twenty-four years up until her husband's death. In Bamako, upon their return they had first stayed with extended family from the region of Kayes until they were able to find a place their own. When her husband died, Rama returned to Senegal where she had left her elder children with her family. Those of her children born in Bamako and who married there stayed in Mali. But some also came back with her to Senegal, others joined her later. She regularly comes back to Bamako to visit her family, particularly for funerals.

This family history is quite exceptional, as it seems to encapsulate most of the migratory trends experienced in the Kayes region over the twentieth century. It clearly shows, over several generations, how marriages between families migrating to Senegal, all originally from the Kayes region, furthered family migratory networks between Senegal and Mali. Rama herself realized at the end of the interview that, except for her twin sister who married a Senegalese, all the people of her family were married off with migrants originally from Mali. Rama's

22 Interview Kidira, Senegal: Ibrahima Dabo. 22 November 2003.

23 Interview Dakar, Senegal: Rama Diakhaté. 14 November 2003. 
story demonstrate how multilocality could be reinforced by fostered children and how in case of widowhood, family networks could be reactivated.

At first, Rama did not think that one day she would return to live in Senegal but as her family and her elder children lived there, she preferred to resettle in Dakar with her children upon the death of her husband. In the case of widows still young enough to remarry, they normally return to stay with their parents. The censuses of Français-Kouta taken between 1929 and 1935 prove abundant migratory movement in the general framework of widowhood. ${ }^{24}$ They show that, according to the circumstances and as seen in the history of Rama, older women often resettled with one of their grown-up children if they had not already been living there. In some cases, they would go to stay with a brother, a sister, a niece or a nephew, or any family member who could protect and support them. According to the census of Français-Kouta, the head of the family, Fodé, welcomed his wife's mother, Sitan, into his home. Other heads of family, Laminin and Mamadi, had each received an aunt. Bakari and Demba, took on their mother-in-law. Further Noumouké allowed Dianké, the third wife of his deceased brother who had died a few years before, to resettle in the Bougouni region where it was highly likely she would be staying with a family member. In most cases, these women were already elderly ones, who had few chances to get remarried, which probably explains their relatively high mobility.

Indeed, the return to a member of one's own family upon widowhood was not always straightforward and as in the case of Dianké, some women are known to have had to wait for several years before being allowed to rejoin their family. More often than not, widows were forced to stay in the family of their deceased husband. Analysis of the jurisprudence in the early twentieth century shows us once again the legal efforts made to restrict women's mobility in cases of widowhood, especially when they were still at an age to remarry. According to what the colonial authorities designated as the local custom of "levirate" in the Kayes region, the husband's brothers had often the right to "remarry" the widow in order to prevent lineage land from passing into stranger hands, if the widow was to remarry into another lineage. Remarrying a brother-in-law was for her the only way to securing further access to the deceased husband's land. In some cases, widows could refuse to remarry one of their brother-in-laws on the condition that they would return the bridewealth to their deceased husband's family.

Colonial authorities did not approve of "levirate", but they often tolerated the practice because they relied upon the respect of local customs and power to assert their own power (Roberts, 2009c; Rodet, 2007b). ${ }^{25}$ Indeed, the detailed analysis of jurisprudence shows that the courts in Kayes increasingly and effectively forced the widows to stay in their husband's family. As in the case of

24 ANM Hamdallaye 5 D 2656: recensement de la population indigène. Village de Français-Kouta. Cercle de Bafoulabé. 1930.

25 However, from the 1930s and with the increasing pressure of metropolitan public opinion the colonial authorities progressively changed their approach to levirate. Henceforth they considered it in the same way as forced marriage. The colonial administration began implementing a series of measures to ban forced marriages, which led to the promulgation of the Mandel decree on 15 June 1939 and officially prohibiting levirate, forced and prenubile marriages (Rodet 2012). 
women willing to get divorced, if in the first years of the Kayes court widows were generally allowed to return to their family with their bridewealth and their children, from 1910 it became increasingly difficult for them to obtain such rights in court. In 1907, Dabo whose husband had just passed away asked the court to return to her father with her child and the bridewealth. ${ }^{26}$ But Bira, her husband's brother, insisted on either marrying her or getting the bridewealth back. The court decided that Dabo did not have to marry Bira and that she would keep bridewealth and child with her. Bira went on appeal in July but the court again decided against him. ${ }^{27}$ In January 1910, Maradi explained to the Kayes court that his deceased brother had given four cows to his wife Téréna as bridewealth, saying that according to tradition he wished either to marry her or to recover the bridewealth. ${ }^{28}$ Téréna told the court that her husband had no heir and that Maradi was not his brother and that therefore she refused to marry him. When asked by the court to provide witnesses, Téréna had not any. Marady swore on the Coran that he was telling the truth. And finally, the court declared Maradi as heir to the deceased and consequently Téréna was forced to marry him.

In this latter case, we can see that the issue of religion did not seem to impact the final verdict, although normally, when the litigants were Muslim, the widow was free to dispose of her bridewealth and to live wherever she wished. We can note the confirmation of the development of this specific jurisprudence favouring customary law over Islamic law in the Sakiliba case, which demonstrates some typical attempts by women like men to play on the competition between Islamic and customary law in court in order to win their case (Rodet, 2007b: 583-602). In 1918, Sakiliba, the wife of a railway employee who died in an accident, was obliged, according to local custom, to marry her brother-in-law and to give him the custody of her children, he being considered the rightful heir to the deceased. She could avoid having to marry him by repaying the bridewealth to her family-in-law, but this would not in itself allow her the custody of her children who in all case had to stay with her brother-in-law.

In appeal against the judgment, Sakiliba attempted to play on the different customs and statuses recognized in court in order to return a verdict in her favour. In the first judgment, the two parties were judged according to their non-Muslim status and in accordance with the Khassonke custom, but in appeal, Sakiliba declared herself to be Muslim and consequently unable to marry her brother-in-law, Muslim widows in the Kayes region being entitled to keep their bridewealth and to live wherever they wished to.

However, the court refused to accept Sakiliba's Muslim status since "It is well known that the Khassonke who converted to Islam have not abandoned their customary status, which continues to regulate their family problems".29 The court of Kayes therefore confirmed their first judgment. Sakiliba then tried to

26 ANM 2 M 123: état des jugements rendus en matière civile et commerciale par le tribunal de province de Kayes. $2^{\text {nd }}$ trimester 1907.

27 Id., état des jugements rendus en appel, en matière civile, par le tribunal de province de Kayes. $3^{\text {rd }}$ trimester 1907.

28 Id., état des jugements rendus en matière civile et commerciale par le tribunal de province de Kayes. $1^{\text {st }}$ trimester 1910.

29 ANS GGAOF (FA) M 93: judgment \#14. Appel d'un jugement en matière civile. Sakiliba 
plead her case with the colonial administration, which eventually decided not to interfere into "indigenous affairs" in respect of customary law. Four years later, following this case an official circular was released insisting on the centrality of respecting local customs pertaining to family law. ${ }^{30}$ This is salient to the case of understanding of how local politics pertaining to family law could influence colonial politics on a broader level.

The Sakiliba case demonstrates how women were able to address their complaints to the colonial administration. Women became gradually aware of how colonial administration worked, and attempted to take advantage of it. However these opportunities started becoming increasingly restricted from 1910 onwards, as both the colonial administration and the local powers had a growing common interest in maintaining the "traditional" family structure. The administration encouraged in particular the courts to more strictly control women's mobility in and out of marriage by not disapproving local court sentences which forced women to stay with their families-in-law in cases of widowhood.

Another case shows how men similarly attempted to use the recognition of different "personal statuses" within the same colonial legal system to force widows to stay with their in-laws. In 1920, Boubou whose deceased eldest son was married to Niansa, requested the court to force Niansa to marry his other son. ${ }^{31}$ But Niansa's father explained to the court that the Muslim custom did not oblige widows to marry their bother-in-law. The court dropped all charges against Niansa provoking a fresh appeal against this judgement from Boubou during which he once again demanded that unless Niansa marries his son the bridewealth should reimbursed..$^{32}$ Niansa's father claimed that Boubou who was a Soninke from Kaarta had changed his status on purpose so that the Bambara custom and not the Islamic law would be applied in this case. He explained that neither the Soninke nor the Islamic law would oblige widows to marry their brother-in-law. The court upheld the first judgment.

If this circumventing strategy of status change between Islamic and customary law did not operate in a region such as Nioro where Islam was more established, it was systematically employed by courts in Kayes, as the Sakiliba case demonstrates, but also here in the courts of Bafoulabé: In 1925, Aldiouna explained to the Kadi who presided over the court of Bafoulabe that his brother had died in Kayes the year before and that his sister-in-law, Coura, subsequently refused to marry him because she had already made arrangements to marry another man, while Coura claimed that Aldiouna was not her brother-in-law. ${ }^{33}$ However, in the Aldiouna vs. Coura case the witnesses confirmed the declarations of Aldiouna. As in the Sakiliba case, although Coura declared to be Muslim, the case was judged according to the Malinke custom. Coura was ordered by the

c/ Coulibaly. Succession. 15 March 1918.

30 CAOM FM AFF POL 541: circular Brunet \#91. A/s. du mariage indigène et des droits résultant de la puissance maternelle, tutélaire ou maritale. 5 October 1920.

31 ANM 2 M 135: état des jugements rendus en matière civile et commerciale par le tribunal de subdivision de Nioro. April 1920.

32 Id: état des jugements rendus sur appel en matière civile et commerciale par le tribunal de cercle de Nioro. May 1920.

33 ANM Hamdallaye 1 M 895: état des jugements rendus en appel, en matière civile, par le tribunal de $2^{\text {nd }}$ degré de Kayes. June 1925. 
court to live with her brother-in-law against which she unsuccessfully appealed, as the court confirming its first judgment went on to condemn Coura to a fiftyfranc fine for improper appeal.

For widowed women, in the same way as for deserting women, success in cutting ties with family-in-law became an important central issue as it meant achieving remarriage, and where possible enhancement of social and financial status by such remarriage. Thus, some women played on the legal pluralism of the native courts to come up with diverse bricolages which should suit the already shifting colonial and social environment, in which the colonial power contributed further to the increasing complexity of relations between African women and the local power. But these strategies had to deal with the strength of the already existing colonial policy agenda towards Muslim and non-Muslim powers, which made such strategies increasingly unsuccessful (Rodet, 2011).

Indeed, local courts were encouraged in their own jurisprudence as colonial power could be seen to approve of their decisions by conspicuously refusing to interfere with "customary law issues", as previously seen in the Sakiliba case. We can see the increasing use of similar jurisprudence in the case of widowhood, desertion or divorce, by claiming a lack of valid grounds with the intention that women should stay with the family of the husband, and therefore favouring their husband's social and family networks over theirs. As in the case of the "family visit", women's circumventing strategies to enhance their mobility, notably by claiming to be of Muslim or non-Muslim status in case of widowhood, failed owing to patrilinear family networks proving ultimately to be much stronger in the region thanks to the support of the colonial authorities.

\section{Conclusion}

In the Kayes region, migratory opportunities in the main depended specifically upon the behaviour patterns of the different family members and the different interactions between them. Marriages in neighbouring regions encouraged the beginning of new migratory networks or their consolidation in the case of family members having already migrated there. Female migration relied mainly upon such family networks having been frequently set up over several generations and which supported further circulation and multilocality. This phenomenon of multilocality demonstrates a serious circulation of women and young girls within the rural areas, as well as in between these rural areas and colonial cities.

However, the colonial authorities and the local power were unwilling to facilitate this situation and did all possible to control and limit female migration in and out of marriage by implementing specific jurisprudence against divorce, desertion of the marital home and mobility in case of widowhood. In the first years of this restrictive jurisprudence, women were still able to circumvent it by employing such strategies as the family visit and religious belonging in order to slip through the legal net. But this would soon become increasingly impossible because of the stringent reinforcement of patrilinear family networks through the colonial moral economy. 


\section{References}

Adams Adrian (1977) Le long voyage des gens du fleuve, Paris, Maspero, 222 p.

Barnes Teresa A. (1999) "We Women Worked so Hard." Gender, Urbanization and Social Reproduction in Colonial Harare, Zimbabwe. 1930-1956, Portsmouth, Heineman, 204 p.

Barnes Teresa A. (2002) Virgin Territory? Travel and Migration, in Jean Allman, Susan Geiger and Nakanyike Musisi Eds., Women in African Colonial Histories, Bloomington \& Indianapolis, Indiana University Press, pp. 164-190.

Boyd Monica (1989) Family and Personal Networks in International Migration: Recent Developments and New Agendas, International Migration Review, 23 (3), pp. 638-670.

Bozzoli Belinda (1991) Women of Phokeng. Consciousness, Life Strategy and Migrancy in South Africa, 1900-1983, Portsmouth, Heinemann, 292 p.

Burrill Emily (2007) Meaning of Marriage in a Market Town: Gender, Conjugality, and Law in Sikasso, French Soudan, 1895-1960, PhD Dissertation, Stanford University, 248 p.

Coquery-Vidrovitch Catherine (1994) Les Africaines. Histoire des femmes d'Afrique noire du XIXe au XXe siècle, Paris, Éd. Desjonqueres, 400 p.

Cordell Dennis D., Gregory Joel W. and Piché Victor (1996) Hoe and Wage. A Social History of a Circular Migration System in West Africa, Boulder, Westview Press, $384 \mathrm{p}$.

Dougnon Isaïe (2007) Travail de Blanc, travail de Noir. La migration des paysans dogon vers l'Office du Niger et au Ghana (1910-1980), Paris, Karthala, 280 p.

Fan C. Cindy and Huang Youquin (1998) Waves of Rural Brides: Female Marriage Migration in China, Annals of the Association of American Geographers, 88 (2), pp. 227-251.

Findley Sally E. and Diallo Assitan (1995) Interactions Between Household Structure and Female Migration in Rural Mali, in Paulina Makinwa and An-Magritt Jensen Eds., Women's Position and Demographic Change in Sub-Saharan Africa, Liege, International Union for the Scientific Study of Population, pp. 271-289.

Goerg Odile (2004) Femmes et hommes dans les villes coloniales : I'illusion du déséquilibre permanent, in Philippe Denis et Caroline Sappia Éds., Femmes d'Afrique dans une société en mutation, Louvain-La-Neuve, Bruylant-Academia, pp. 27-48.

Goerg Odile (2005) Les femmes, citadines de deuxième plan ? Réflexion sur le sex ratio dans les villes en Afrique sous la colonisation, in Chantal ChansonJabeur et Odile Goerg Éds., Mama Africa: Hommage à Catherine CoqueryVidrovitch, Paris, L'Harmattan, pp. 143-168.

Konaté Famagan Oulé (2010) La migration féminine dans la ville de Kayes au Mali, Hommes et migrations, 1286-1287, pp. 62-73.

Lambert Michael C. (2002) Longing for Exile. Migration and the Making of a Translocal Community in Senegal, West Africa, Portsmouth, Heinemann, 191 p.

Manchuelle François (1997) Willing Migrants. Soninke Labor Diasporas, 18481960, Athens, Ohio University Press, 371 p. 
Mbilinyi Marjorie (1989) Women's Resistance in Customary Marriage: Tanzania's Runaway Wives, in Abede Zegeye and Shubi Ishemo Eds., Forced Labour \& Migration: Patterns of Movement within Africa, London, Hans Zell Publishers, pp. 211-254.

Pflegerl Johannes (2003) Family and Migration Research Developments in Europe: A General Overview, in Johannes Pflegerl et al., Researching Migration and the Family, Singapore, Asian MetaCentre for Population and Sustainable Development Analysis, pp. 59-110.

Roberts Richard (2005) Litigants and Households: Colonial Courts and African Disputes in the Fench Soudan, 1895-1912, Portsmouth, Heinemann, 310 p.

Roberts Richard (2009) Voices of Slavery in the Colonial Courts of French West Africa in the Aftermath of Slavery, Paper presented at the Tales of Slavery: Narratives of Slavery, the Slave Trade, and Enslavement in Africa Conference, Toronto, 20-23 May 2009.

Rodet Marie (2007a) Disrupting Masculinist Discourse on African Migration: The Study of Neglected Forms of Female Migration, in Charlotte Baker and Zoë Norridge Eds., Crossing Places: New Research in African Studies, Newcastle, Cambridge Scholars Publishing, pp. 28-38.

Rodet Marie (2007b) Genre, coutumes et droit colonial au Soudan français (19181939), Cahiers d'Études Africaines, 187-188: Femmes, droit et justice, pp. 583-602.

Rodet Marie (2008) Migrants in French Sudan: Gender Biases in the Historiography, in Toyin Falola and Niyi Afolabi Eds., Trans-Atlantic Migration: The Paradoxes of Exile, New York, Routledge, pp. 165-181.

Rodet Marie (2009a) Les migrantes ignorées du Haut-Sénégal, 1900-1946, Paris, Karthala, 348 p.

Rodet Marie (2009b) Genre, migration et réseaux familiaux au Haut-Sénégal, 1907-1950, Revue Diasporas, 11: Etrangères, pp. 25-36.

Rodet Marie (2009c) "Le délit d'abandon de domicile conjugal " ou I'invasion du pénal colonial dans les jugements des " tribunaux indigènes " au Soudan Français (1900-1945), French Colonial History, 10, pp. 149-167.

Rodet Marie (2010) Continuum of Gendered Violence: The Colonial Invention of Female Desertion as a Customary Criminal Offense, French Soudan, 1900-1949, in Emily Burrill, Richard Roberts and Elizabeth Thornburry Eds., Domestic Violence and the Law in Colonial and Postcolonial Africa, Athens, Ohio University Press, pp. 73-94.

Rodet Marie (2011) Islam, pluralisme juridique et relations de genre dans les "tribunaux indigènes " du Soudan français, 1900-1925, Outre-Mers. Revue d'histoire, 99 (370-371), pp. 173-183.

Root Brenda D. and De Jong Gordon F. (1991) Family Migration in a Developing Economy, Population Studies, 45, pp. 221-233.

Schmidt Elizabeth (1992) Peasants, Traders, and Wives. Shona Women in the History of Zimbabwe, 1870-1939, Portsmouth, Heineman, London, James Currey, Harare, Baobab, p. 289.

Walker Cherry Ed. (1990) Women and Gender in Southern Africa to 1945, Cape Town, David Phillip, 390 p. 
Watts Susan J. (1983) Marriage Migration, a Neglected Form of Long-Term Mobility: A Case Study from Ilorin, Nigeria, International Migration Review, 17, pp. 682-698.

Weigel Jean-Yves (1982) Migration et production domestique des Soninké du Sénégal, Paris, ORSTOM, $134 \mathrm{p}$.

Women in Action (2007) Special Issue Marriage Migration, 3.

Wright Caroline (1995) Gender Awareness in Migration Theory: Synthesizing Actor and Structure in Southern Africa, Development and Change, 26 (4), pp. 771-791. 


\section{Marie Rodet}

\section{$\cdots$ Historical Perspectives on Marriage, Migration, and Family Networks in the Region of Kayes, Mali}

In this article, the author argues that migration scholars can gain a wider understanding of historical African migration through the examination of marriage migration in particular. These specific migrations, which are especially visible in civil legal records of the Kayes region (Mali) from 1905 to 1925, shed light on women's mobility (social and geographical) in and out of marriage. These documents also show the gradual restriction of this mobility by colonial and local authorities. The circumventing strategies used by some women to counter these restrictions relied mainly upon historical family migration networks. But these strategies would gradually become obsolete owing to patrilinear family networks proving ultimately to be much stronger thanks in particular to the colonial authorities' support.

\section{Perspectives historiques sur le mariage, les migrations et les réseaux familiaux dans la région de Kayes, Mali}

Dans cet article, l'auteure montre que les chercheurs spécialistes des migrations peuvent développer une meilleure compréhension de l'histoire des migrations africaines en examinant les migrations de mariage. Ces migrations spécifiques, particulièrement visibles dans les affaires judiciaires jugées au civil de 1905 à 1925 dans la région de Kayes (Mali), mettent en lumière les stratégies matrimoniales des femmes pour accéder à une mobilité sociale et géographique. Ces documents montrent également les restrictions mises en place par les autorités locales et coloniales pour limiter ces mobilités. Les stratégies de contournement utilisées par certaines femmes pour contrer ces restrictions s'appuient principalement sur des réseaux migratoires familiaux historiques. Mais ces stratégies deviendront progressivement obsolètes du fait des réseaux familiaux patrilinéaires qui s'avèreront finalement les plus puissants, grâce, notamment, au soutien des autorités coloniales.

\section{..? Perspectivas históricas sobre casamiento, migración y redes familiares en la región de Kayes, Mali}

En este artículo, el autor demuestra que los investigadores sobre migración pueden desarrollar un mejor entendimiento de la historia de las migraciones africanas con el enfoque particular de las migraciones de casamiento. Este tipo de migración especifico, que se destaca particularmente a través de los casos judiciales juzgados al civil entre 1905 y 1925 por la región de Kayes (Mali), revela una movilidad (social y geográfica) de las mujeres tan al entrar como al salir del vínculo matrimonial. Estos documentos exponen también a las restricciones crecientes establecidas tanto por autoridades locales como coloniales para limitar esta movilidad. Las estrategias de elusión usadas por algunas mujeres para contrarrestar estas restricciones se basaron principalmente en redes migratorias familiares históricas. Sin embargo, estas estrategias se tonarán gradualmente anticuadas por culpa de redes familiares patrilineales que se revelarán al final como más potentes, en particular por el apoyo de autoridades coloniales. 